\title{
Dar nombre a lo ignoto Idilio y tragedia en Hölderlin (con una coda celaniana)
}

\author{
Anacleto Ferrer
}

Recibido: 26.11.2021 — Aceptado: 15.12.2021

\section{Titre / Title / Titolo}

Nommer l'inconnu. Idylle et tragédie chez Hölderlin (avec une coda célanienne)

Naming the unknown. Idyll and tragedy in Hölderlin (with a Celanian coda) Dare un nome all'ignoto. Idillio e tragedia in Hölderlin (con una coda celaniana)

\section{Resumen / Résumé / Abstract / Riassunto}

El 4 de junio de 1799, en carta a Neuffer, Hölderlin cita por vez primera el nombre de una obra que dice tener «acabada exceptuando el último acto». Se llamará «La muerte de Empédocles». Se propone publicarla en los primeros números de una revista poética mensual «para damas» que tiene la intención de dirigir si consigue interesar en el proyecto al editor Johann Friedrich Steinkopf. Se llamará Iduna. De los trabajos asociados al plan de Iduna solo pervivirán fragmentos y el texto acabado que Steinkopf le encargara sobre Emilia. La redacción de Empédocles y Emilia coinciden en el tiempo, de un lado una tragedia poetológicamente fundamentada, del otro un idilio sentimental solo aparentemente de circunstancias. A través de uno y otro texto, desarrollados en una época de inestabilidad política acusada, el poeta responde (o al menos lo intenta) a su propio interrogante: ¿Para qué poetas en tiempo menesteroso? Es ésta una cuestión a la que también se enfrentará siglo y medio después Paul Celan.

Le 4 juin 1799, dans une lettre à Neuffer, Hölderlin mentionne pour la première fois le nom d'une pièce de théâtre qu'il dit avoir «terminé sauf le dernier acte». Il doit s'appeler «La mort d'Empedocles». Il a l'intention de la publier dans les premiers numéros d'une revue poétique mensuelle «pour dames» qu'il compte éditer s'il parvient à intéresser l'éditeur Johann Friedrich Steinkopf au projet. Elle s'appellera Iduna. Des œuvres associées

Escrito con ocasión del 250 aniversario del nacimiento de Hölderlin (1770-1843) y del centenario del de Celan (1920-1970) para el seminario «Palabra poética. Hölderlin y Celan, hendiduras en el camino del Pensar» organizado por la Cátedra Internacional de Investigación en Hermenáutica Crítica HERCRITIA. Aunque estaba previsto que se celebrase en la primavera de 2020, la pandemia obligó a retrasarlo al otoño de 2021. El texto fue presentado en la $6^{\mathrm{a}}$ sesión (26 de noviembre). au plan Iduna, seuls des fragments et le texte achevé sur Emilia, commandé par Steinkopf, survivront. L'écriture d'Empédocle et d'Emilia coïncide dans le temps, d'un côté une tragédie fondée sur la poésie, de l'autre une idylle sentimentale qui n'est qu'apparemment de circonstance. À travers ces deux textes, qui ont été écrits dans une période d'instabilité politique marquée, le poète répond (ou du moins tente de répondre) à sa propre question: pourquoi des poètes en temps de crise ? C'est une question à laquelle Paul Celan sera également confronté un siècle et demi plus tard.

On June 4th, 1799, in a letter to Neuffer, Hölderlin cites for the first time the name of a play he claims to have «finished except for the last act». It is to be called «The Death of Empedocles». He intends to publish it in the first issues of a monthly poetic magazine «for ladies» which he plans to be the editor of if he succeeds in envolving the publisher Johann Friedrich Steinkopf in the project. It will be called Iduna. Of the works associated with the Iduna plan, only fragments and the finished text that Steinkopf commissioned him to write about Emilia will survive. The writing of Empedocles and Emilia coincide in time, one a poetically grounded tragedy, the other a sentimental idyll only apparently of circumstance. Through both texts, developed in a time of marked political instability, the poet answers (or at least tries to) his own question: Why poets in times of need? This is a question that Paul Celan will also face a century and a half later.

Il 4 giugno 1799, in una lettera a Neuffer, Hölderlin menziona per la prima volta il nome di un'opera teatrale che dice di aver «finito tranne l'ultimo atto». Si chiamerà «La morte di Empedocle». Ha intenzione di pubblicarlo nei primi numeri di una rivista poetica mensile «per signore» che intende curare se riesce a interessare l'editore Johann Friedrich Steinkopf al progetto. Si chiamerà Iduna. Delle opere associate al piano Iduna, sopravviveranno solo frammenti e il testo finito sull'Emilia commissionato da Steinkopf. La scrittura di Empedocle ed Emilia coincidono nel tempo, da una parte una tragedia poeticamente fondata, dall'altra un idillio sentimentale solo apparentemente di circostanza. Mediante i due testi, scritti in un periodo di marcata instabilità politica, il poeta risponde (o almeno tenta di rispondere) alla sua propria domanda: perché i poeti in tempi di bisogno? Questa è la domanda che anche Paul Celan affronterà un secolo e mezzo più tardi. 


\section{Palabras clave I Mots-clé I Key words I Parole chiave}

Tragedia, idilio, Hölderlin, Celan.

Tragédie, idyll, Hölderlin, Celan.

Tragedy, idyll, Hölderlin, Celan.

Tragedia, idillio, Hölderlin, Celan.

Hölderlin fue un vir clarus.

Paul Celan

La primera mención de Hölderlin a su voluntad de abordar un proyecto dramático la encontramos en una carta que remite a Christian Ludwig Neuffer el 10 de octubre de 1794, desde Waltershausen, en la cual, tras anunciarle la pronta publicación en la revista Thalia de las «cinco primeras cartas» de la novela que está escribiendo, le confiesa: «Por cierto que no por eso deja de alegrarme pensar en el día en que haya acabado con todo, porque entonces atacaré inmediatamente otro plan que casi me importa más: elaborar la muerte de Sócrates según los ideales de los dramas griegos». ${ }^{1}$ En el empeño por actualizar «los ideales de los dramas griegos», Hölderlin no estará solo: en 1800 Schiller se lo propondrá en La novia de Mesina, obra de un simbolismo fatalista al estilo sofocleo en la que pone un coro sobre el escenario (Ryan, 34).

En agosto de 1797, desde Fráncfort, habiendo publicado ya el primer volumen de Hiperión o el eremita en Grecia, Hölderlin informa a su hermanastro Karl Gock: «Mi Hiperión me ha valido algunas palabras hermosas. [...] He hecho un plan detallado para una tragedia, cuyo tema me arrebata». ${ }^{2}$ Se trata del llamado Plan de Fráncfort para Empédocles, que traza en un cuaderno escolar de su

Hölderlin, F. (1990): Correspondencia completa (HCC). Trad. de Helena Cortés y Arturo Leyte. Hiperión, Madrid, ${ }^{\circ} 88$.

HCC, $n^{\circ} 142$ pupilo Henry Gontard en el que ya había pergeñado un primer borrador de las cartas 14 a la 19 del volumen segundo de Hiperión. ${ }^{3}$ Hölderlin prevé que el drama tenga cinco actos.

Por fin, el 4 de junio de 1799, otra vez en carta a Neuffer, ${ }^{4}$ cita por vez primera el nombre de esa obra que dice tener «acabada exceptuando el último acto». Se llamará «La muerte de Empédocles». Se propone publicarla en los primeros números de una revista poética mensual «para damas» que tiene la intención de dirigir si consigue interesar en el proyecto a Johann Friedrich Steinkopf, que ya editaba un almanaque a Neuffer. Hölderlin ha tenido que abandonar Fráncfort y ha sido acogido por Isaac von Sinclair en Homburgo. Ahora necesita perentoriamente una ocupación con la que ganarse el sustento. Cuando, el 13 de junio, Steinkopf da su conformidad le pone como condición que consiga colaboradores de renombre y le pide que, para darse a conocer entre sus futuras lectoras, componga «un relato o novela muy breve, sobre Emilia». ${ }^{5}$ El idilio Emilia en vísperas de su boda verá la luz en el almanaque de Neuffer del año 1800. También el 4 de junio de 1799, en carta al hermano, Hölderlin transcribe un pasaje de la segunda versión de su tragedia para que Karl pueda «ver aproximadamente el tono y espíritu del escrito» del que ahora se ocupa «con pausado amor y trabajo». ${ }^{6}$

Escrito y entregado el texto sobre Emilia, el poeta, cuya situación económica es cada vez más precaria, escribe a la madre, el 4 de septiembre, para agradecerle un envío de dinero, que empleará, le explica, «en vivir todavía algún tiempo en una diaria aplicación, sobre todo para darle todavía a la obra» que tiene entre manos «toda la perfección» de que es capaz. ${ }^{7}$ Pero en la segunda mitad de ese mismo mes ve cómo sus esfuerzos se encaminan al fracaso. A su «queridísima» Susette le anuncia: «tengo la intención de dedicar todo el tiempo

\footnotetext{
Hölderlin, F. (1989): Hiperión. Versiones previas (HVP). Trad. de Anacleto Ferrer. Hiperión, Madrid, pp. 203-210.

HCC, $\mathrm{n}^{\circ} 178$.

Hölderlin, F. (1992 ss.): Sämtliche Werke und Briefe (SWB). Carl Hanser Verlag, Múnich, II, 773-774.

HCC, $\mathrm{n}^{\circ} 179$

HCC, $n^{\circ} 193$
} 
que aún me resta a mi tragedia, lo que todavía puede durar un cuarto de año». ${ }^{8}$

Cuando en el verano de 1800 Hölderlin abandone Homburgo para trasladarse a Stuttgart, dejará tras de sí las tres versiones inacabadas de La muerte de Empédocles, su única incursión dramática, así como las últimas esperanzas que tenía de poder «vivir solo de la escritura».9 De los trabajos asociados al plan de Iduna, el almanaque que no llegará a nacer, solo pervivirán fragmentos y el texto acabado que Steinkopf le encargara sobre Emilia.

\section{Poesía e historia}

Hölderlin empieza a trabajar en su tragedia en una época de excitación política general. Transformar la realidad según las nuevas concepciones, aproximándola a una utopía social que —a juzgar por la moderna visión universal del hombre, de la sociedad y del Estado que el movimiento revolucionario ofrecía a los pueblos europeos - parecía ahora más posible que nunca.

Con su poesía, Hölderlin quiere influir en los planes del movimiento patriótico wurtemburgés, que aspira a la construcción de una República Suaba, intentando perfilar las condiciones de un cambio cultural radical (Grätz, 99). Estas esperanzas, que el vate comparte con los amigos del círculo de Homburgo, se irán modificando conforme vaya viendo, a partir de marzo de $1799,{ }^{10}$ que los franceses no están dispuestos a promover la formación de repúblicas en suelo alemán.

Pero, aunque acabe considerando la dictadura de Napoleón como una traición al ideario republicano, Hölderlin no dejará de creer en los ideales de fraternidad, igualdad y libertad nacidos de la revolución y nunca dejará de aspirar a la construcción de una Alemania democrática ajena a toda clase de despotismo, divino o humano, revolucionario o feudal.

\footnotetext{
HCC, $\mathrm{n}^{\mathrm{o}} 195$.

HCC, $\mathrm{n}^{\circ} 202$.

Bertaux, P. (1992): Hölderlin y la Revolución Francesa. Ediciones del Serbal, Barcelona, pp. 105-114.
}

«Una emoción sublime reinaba en aquel tiempo; el entusiasmo estremeció al mundo, como si solo entonces se hubiese llegado a la efectiva reconciliación de lo divino con el mundo», así concluye Hegel el fragmento de sus Lecciones sobre la Filosofía de la Historia Universal, dedicado a «Elpensamiento revolucionario». Y de eso es precisamente de lo que tratará Empédocles: de la palabra poética como mediación entre lo sagrado y lo mundano, como punto de intersección entre el poder de los dioses y la libertad de los hombres; del destino del poeta en un tiempo menesteroso: el momento en que una sociedad y una cultura anquilosadas se quiebran para que de sus ruinas emerja un orden nuevo.

\section{Materias trágicas y materias sentimentales}

El 3 de julio de 1799, un par de semanas después de haber recibido la petición de Steinkopf, Hölderlin remite a Neuffer su Emilia; se trata de un relato epistolar poetizado en 603 yambos de cinco pies. Al manuscrito le acompaña una carta en la que Hölderlin cuenta a su amigo «algo acerca del método y la manera» en que ha compuesto esta obrita: «Por muy a la ligera que haya escrito este ensayo, con todo te puedo decir que soy consciente de haber escrito muy pocas cosas sin algún fundamento dramático o generalmente poético», le confiesa. La incomparable poesía de Hölderlin viene siempre acompañada de cogitaciones poetológicas que no le van nunca a la zaga. Así, en las Notas sobre Edipo opondrá el «cálculo legal (gesetzliche Kalku) [...] por el cual lo bello es producido» (Hölderlin, 134) a los caóticos desenfrenos del Romanticismo febril. «Allí donde la sobriedad te abandona, allí está el límite de tu entusiasmo. El gran poeta nunca está olvidado de sí mismo, por mucho que se eleve por encima de sí mismo. Se puede también caer en la altura, tanto como en el abismo», observa en una de la «reflexiones» que escribe durante la estadía en Homburgo, probablemente para la revista Iduna (ibid., 46). 
Mas ¿en qué consiste ese «fundamento» — cuál es el «cálculo legal» que lo constituye- que en otro pasaje de la misma carta asegura haber «proyectado desde hacía bastante tiempo»? Hölderlin lo explica:

En cuanto tratamos una materia que sea aún mínimamente un poco moderna, tenemos que abandonar las antiguas formas clásicas, las cuales están tan íntimamente adaptadas a su materia que no sirven para ninguna otra. Naturalmente ahora estamos acostumbrados a que por ejemplo una historia de amor que no es más que eso aparezca bajo la forma de una tragedia, aunque entre los antiguos la tragedia no se adaptaba nada a una auténtica historia de amor, según su propio desarrollo interno y su diálogo heroico. Si se conserva el diálogo heroico, siempre da la impresión como si los amantes riñesen. Si se lo abandona, entonces el tono se contradice con la forma propia de la tragedia, que naturalmente ya no se mantiene en absoluto de modo estricto y por eso mismo ha perdido entre nosotros su valor poético propio y su significado.

Así pues, una sencilla historia de amor, si se sirviere de «la tan digna de respeto forma trágica», la rebajaría «a mero medio para decir algo brillante o tierno». Dicha «forma» es, a juicio de quien desde hace meses consume su tiempo y sus fuerzas componiendo una tragedia:

La más estricta de todas las formas poéticas, que está completamente dispuesta para sin ningún tipo de adorno, casi solo a base de grandes tonos, de los que cada uno es un todo propio, progresar de modo cambiante pero armónico, y que en ese orgulloso rechazo de todo lo accidental presenta el ideal de un todo vivo tan breve y al mismo tiempo tan completamente y con tanta riqueza de contenido como es posible, y por ello también de modo más claro, pero también más seriamente que cualquier otra forma poética. ${ }^{11}$

De las «materias trágicas» se distinguen las «sentimentales», a las que pertenece Emilia en vísperas de su boda, en la manera en que éstas se sirven de «lo accidental», término con el cual Hölderlin alude a los detalles concretos y a los tonos y motivos secundarios.

Schiller, en el ensayo Sobre poesía ingenua y sentimental (Über naive und sentimentalische Dichtung), que había visto la luz en la revista Horen cuatro años antes, había distinguido dos formas del quehacer poético: «El poeta, [...], o es naturaleza o la buscará; de lo uno resulta el poeta ingenuo, de lo otro el sentimental». Mientras al primero, por no haber perdido la unidad con la naturaleza que caracteriza a la antigüedad clásica, lo que le hace «debe ser la imitación, lo más acabada posible, de la realidad»; al segundo, enajenado ya de la naturaleza, lo que le hace «debe ser el elevar la realidad a ideal o, en otras palabras, la representación del ideabir. En una nota al párrafo titulado Idilio, Schiller enuncia las características definitorias de las tres especies poéticas sentimentales según la clase de relación que en cada una de ellas entabla el ideal con la experiencia, o si se prefiere, y por emplear el mismo lenguaje que Hölderlin en su carta, con «lo accidental»:

Esta poesía sentimental se distingue de la ingenua en que refiere a ideas la realidad ante la cual la ingenua se detiene, y en que aplica ideas a lo real. Por eso, siempre tiene que vérselas al mismo tiempo [...] con dos objetos en pugna, a saber, con el ideal y la experiencia, entre los cuales no pueden concebirse ni más ni menos que tres relaciones. $\mathrm{O}$ es la contradicción de la realidad con el ideal, o bien su armonía, lo que ocupa preferentemente el ánimo, o éste se siente dividido entre lo uno y lo otro. En el primer caso encuentra satisfacción por la intensidad de la lucha íntima, por el movimiento enérgico; en el otro por la armonía de la vida interior, por la serenidad enérgica; en el tercero alternan la lucha y la armonía, la serenidad y el movimiento. Esta triple situación afectiva da origen a tres distintas especies de poesía, a las cuales corresponden perfectamente las usuales designaciones de sátira, idilio y elegía, con solo tener presente la disposición en que colocan al espíritu los modos de poesía existentes bajo esas denominaciones, y en cuanto dejamos a un lado los medios con que obtienen ese efecto.

Resumamos: tragedia e idilio expresan, según el autor de Empédocles y Emilia, «el ideal de un todo vivo». La tragedia lo presenta «a base de tonos grandes, orgullosos y firmes y con un rechazo decidido de lo accidental»; el idilio, con «la serenidad de la perfección», ${ }^{12}$ no negando la realidad, sino idealizándola con «un tierno temor de lo accidental».

\footnotetext{
12 Schiller, F. (1985): Sobre la gracia y la dignidad. Sobre poesía ingenua y poesía sentimental. Icaria, Barcelona, pp. 90-126.
} 


\section{El idilio}

Emilia en vísperas de su boda, en justa correspondencia con esa caracterización de las formas poéticas, es el contrapunto idílico-armónico de la problemática trágico-heroica de Hiperión o el eremita en Grecia.

A principios de noviembre de 1799, todavía desde Homburgo, Hölderlin envía a Susette un ejemplar del segundo volumen de la novela, que acaba de editar Cotta, y con él, una carta:

¡He aquí nuestro Hiperión, querida! Este fruto de nuestros días inspirados te procurará sin duda algo de alegría. Perdóname que muera Diotima. Recuerda que ya entonces nunca pudimos ponernos completamente de acuerdo sobre este punto. $\mathrm{Me}$ pareció que sería necesario, habida cuenta de todo el planteamiento. ${ }^{13}$

La protagonista del nuevo texto, por contra, no muere; salva su identidad en el puerto feliz del idilio: se promete en matrimonio. El ideal no sucumbe, sino que se realiza — si bien limitadamente - en la fundación de un hogar burgués. La historia es la siguiente: el único hermano de Emilia, Eduardo, que ha partido hacia Córcega para unirse a la sublevación democrática que acaudilla Pasquale Paoli, muere en un enfrentamiento con el enemigo. Ella, en un intento por superar su aflicción, emprende un viaje con su padre. En el histórico bosque de Teutoburgo conoce a un extraño de asombroso parecido con Eduardo; su nombre: Armenion. Emilia se enamora de él, quien viaja tras ella, le confiesa su amor por carta y la pide a su padre en matrimonio. Final feliz para «una historia de amor que no es más que esa». ¿Nada más que eso?

Pero no solo la acción del idilio remite expresamente a Hiperión; la forma también lo hace: el poema consta de siete cartas que Emilia hace llegar a Clara en vísperas de su boda. Cabe pensar, sin miedo a equivocarse, que la resolución positiva de la temática heroico-trágica y el tono idílico a ella asociado dependen directamente del

HCC, n n $^{\circ} 198$. modelo de lector que el poeta se ha forjado: se trata de una historia de mujeres y para mujeres, de ahí su sencillez y aparente levedad. El idilio es — siguiendo la estela de Schiller - una manera grácil de armonizar el ideal con la realidad.

Una ojeada a la correspondencia entre Hölderlin y Schiller, y a la de éste con Goethe a propósito de aquél, tal vez alumbre los motivos que le inducen a adentrarse en la terra incognita de la poesía idílica.

En una carta fechada el 24 de noviembre de 1796 en Jena, en respuesta a otra de Hölderlin de cuatro días antes en que le instaba a que le hiciese saber «su opinión sincera» sobre unos versos remitidos desde Kassel en julio, «pues también en lo tocante a eso» soporta «cualquier cosa mejor que su silencio», ${ }^{14}$ Schiller le aconseja que «concentre toda su fuerza y su atención y elija una materia poética feliz», que «huya en la medida de lo posible de las materias filosóficas» y que «permanezca próximo al mundo de los sentidos» (Schiller, 641). En términos parecidos se expresa también Goethe en la carta que el 28 de junio del 97 dirige a Schiller desde Weimar para comentarle, como aquél le había pedido, un par de poemas de Hölderlin: «Quizás haría mejor si eligiese un factum idílico muy sencillo y lo representase, así se podría ver antes qué tal se le da la pintura de seres humanos, que es al fin y al cabo lo principal de todo»(Schiller, 594). Transcurridos dos meses, Goethe vuelve a cartearse con Schiller, esta vez desde Fráncfort, para hablarle de «Hölterlein», al que ha exhortado a escribir «pequeños poemas» y escoger temas «de interés humanos» para sus composiciones (Schiller, 598).

A la luz de estos testimonios el idilio que es Emilia se nos muestra con un perfil nuevo: se trata de una tarjeta de presentación con la que el poeta no solo pretende atraer sobre sí la atención de las posibles lectoras de su futura revista, sino granjearse el favor, acatando sus consejos, de Goethe y Schiller. Y muy en especial de este último, que había teorizado sobre el idilio en el ensayo citado, y cuya firma en las páginas de Iduna era condición indispensable para el editor Steinkopf. 


\subsection{La guerra}

Durante la visita que ambos realizan a Atenas, Diotima había profetizado a Hiperión: «Serás educador de nuestro pueblo» (Hölderlin, 125). Hölderlin hace suya una vez más esta misión pedagógica y no desaprovecha la ocasión que se le tercia de dirigirse a un público que no es el que le lee normalmente, entreverando con sus ideales sociopolíticos esa sencilla historia de amor dirigida a las mujeres que será Emilia. Eduardo, que participa como voluntario en la lucha de liberación del pueblo corso, paga con su vida la defensa de tan noble causa. Tras su muerte aparece Armenion en escena. También él encarna — si bien bajo presagios distintos - la aspiración a una vida mejor en una sociedad más justa. El padre de Emilia es un hombre venerable que ha educado a sus hijos siguiendo los cánones del mundo clásico. La forma epistolar del relato permite un tratamiento oblicuo de los hechos narrados —los personajes son todos varones, salvo la remitente y la destinataria de las cartas - desde la perspectiva de una mujer. Hölderlin no escapa en lo esencial a los estereotipos de su tiempo: el carácter masculino se distingue por la impronta de la acción, el femenino por la de los sentimientos. También en el caso específico de la literatura para mujeres.

El paralelismo entre los personajes de Emilia e $\mathrm{Hi}$ perión es evidente: allí Adamas, aquí el padre; allí Alabanda, aquí Eduardo; allí Hiperión, aquí Armenion; allí Diotima, aquí Emilia; allí Bellarmino y aquí Clara. Amor y guerra en las dos obras. El desenlace es otro.

Eduardo se enrola en el ejército insurgente que comanda Pasquale Paoli. Éste, que había sido nombrado general por el Gran Consejo de Córcega en 1755, se opuso a la secular dominación genovesa y proclamó la independencia de la isla. Incapaz de sofocar la rebelión corsa, la república de Génova acuerda, en agosto de 1764, permitir que las tropas francesas guarnezcan cinco ciudades. Y en mayo de 1768 firma un tratado con el gobierno francés por el que Córcega es vendida a Francia a cambio de dos millones de livres y una garantía francesa del territorio continental de Génova. Un año le cuesta a Francia acabar con la resistencia de Pasquale Paoli y de sus partidarios; pero en junio de 1769 la isla se encuentra completamente en sus manos y Paoli debe exiliarse a Gran Bretaña. En 1790 la Francia revolucionaria le amnistía y nombra gobernador de Bastia; tres años después intenta recuperar la independencia, pero fracasa y se refugia en Londres en 1795, donde muere el 5 de febrero de 1807. En ochenta y dos años había conocido cincuenta de exilio. En su honor fue erigido un monumento en la catedral de Westminster. ${ }^{15}$

La causa del pueblo corso despertaba simpatías entre los liberales de toda Europa. Cuando en 1769 Paoli atraviesa el continente camino del exilio inglés, su reputación y la de su pequeña patria insular no pueden ser mejores. De vuelta en Córcega, y habiendo sido nombrado gobernador de Bastia por Luis XVI en 1790, protestó enérgicamente contra la ejecución del rey tres años más tarde. La Convención, en manos jacobinas, le declaró traidor. La ruptura con Francia se consumó y la prensa alemana se hizo eco del caso.

Cuando en 1799 Hölderlin escribe y publica su Emilia, la causa corsa conservaba toda su popularidad en la patria del poeta y Paoli seguía siendo admirado como un irredento luchador por la libertad. Que Hölderlin se sume al elogio de Paoli nada tiene de extraño, habida cuenta de que, como éste, condenó sin ambages la política jacobina en los días del Terror, al tiempo que se proclamaba republicano sin demasiadas cautelas.

Pero aún existe otra razón que explica el interés del poeta por la lucha de los corsos. En 1799 los nombres de Córcega y de Paoli estaban inevitablemente asociados al del joven Napoleón Bonaparte, que en los tres últimos años se había convertido en el general más famoso de Francia tras las campañas de Italia y Egipto. Después de los brillantes triunfos frente a las tropas austríacas y las de los reyes y príncipes italianos en 1797 , Hölderlin (27) había compuesto un proyecto de oda en honor al corso victorioso:

Arrighi, P. y Pomponi. F. (1993): Histoire de la Corse. Presses Universitaires de France, París, pp. 59-95. 
Vasos sagrados son los poetas, en los que el vino de la vida, el espíritu de los héroes, se conserva;

Pero el espíritu de este joven, el veloz, ¿no haría estallar el vaso que quisiera contenerlo? ${ }^{16}$

¿Y acaso no es el mismo Buonaparte del poema aquel teniente arrogante que en junio de 1789 agavilla sus Cartas corsas y las envía al ejemplar Paoli, que continúa en el destierro, con esta misiva?: «Si usted se digna, mi general, aprobar este trabajo, si usted se digna dar alientos a un hombre que usted vio nacer, me atreveré a asegurar favorablemente el éxito» (Ludwig, 17-18).

El 16 de noviembre de 1799, cuatro meses después de que Hölderlin enviara a Neuffer la Emilia, y apenas transcurrida una semana del golpe de estado del 18 de Brumario ( 9 de noviembre), escribe a su madre: $« \mathrm{Me}$ he enterado ahora mismo de que el Directorio francés ha sido depuesto, el senado ha sido mandado a St. Cloud y Buonaparte se ha convertido en una especie de dictador». ${ }^{17}$

El poeta continúa siendo un demócrata republicano, y la confesada admiración por el artífice de la paz de Campoformio no le nubla el juicio a la vista de los hechos. Las primeras medidas adoptadas por el general golpista no parecen suscitar dudas en él acerca de cuáles son las verdaderas intenciones que le animan: «Soy enemigo del egoísmo, del despotismo, de la misantropía, pero por lo demás, cada vez amo más a los hombres, porque cada vez veo mejor, en lo pequeño y en lo grande de su actividad y de sus caracteres, el mismo carácter originario, el mismo destino». ${ }^{18}$

\subsection{El viaje}

Tras conocer la noticia terrible de la muerte en batalla de Eduardo, Emilia y su padre emprenden un viaje que

\footnotetext{
Hölderlin, F. (1999): Odas. Trad. de Txaro Santoro. Hiperión, Madrid, p. 27. HCC, n ${ }^{\circ} 199$.

18 HCC, n ${ }^{\circ} 179$.
}

les llevará por «la ribera apacible y bella» del Neckar y las «llanuras del Meno claras y libres» hasta «el país donde está / el valle de Varo». No hacía mucho —en el verano de 1796 - que el propio Hölderlin había transitado por esos mismos lugares con Susette y Heinse, mientras Fráncfort resistía el asedio de los franceses, y aún conservaba fresca en la memoria la huella sensual de sus paisajes (Hock).

Precisamente en ese mismo valle, en el que según cuenta Cornelio Tácito en sus Anales el legado Quintilio Varo fue derrotado el año 9 d.n.e. por los queruscos al mando de Arminio — a quien llama «el liberador de la Germania»—, es donde Emilia conoce al que será su esposo: Armenion. ¿Y acaso el amigo, e interlocutor lejano y silente, del eremita Hiperión no llevaba un nombre afín? Arminio, Bellarmino, Armenion... Variaciones sobre un mismo tema: el de la patria liberada. Afinidad sí, pero electiva.

\subsection{El amor}

«Me gustaría que este libro estuviese abocado a conseguir el amor de los alemanes» (Schiller, 611), son las primeras palabras del prefacio de Hiperión o el eremita en Grecia. El libro está dirigido a un público nacionalmente determinado; los alemanes de las postrimerías del siglo XVIII son los lectores en quienes piensa el poeta al escribirlo. La conocida diatriba que cierra el segundo volumen de la novela alude expresamente también al pueblo alemán; Hiperión acusa, reprende, denuncia en nombre de Bellarmino - es decir, del bello Arminio, prototipo histórico del alemán amante de la libertada los compatriotas de su tiempo.

En este nuevo texto, Emilia encuentra a Armenion - el nombre es ahora el del héroe de los germanos pero con la terminación griega-, a quien de entrada confunde con su hermano muerto, en los aledaños del mítico valle de la batalla contra las tres legiones de Varo.

Desde su primera aparición, la enigmática figura de Armenion sugiere un camino distinto en la lucha por la libertad al que condujo a Eduardo a alistarse en las 
filas de Paoli. Bajo la advocación de Arminio, y como el griego Hiperión al final de su excéntrico periplo - híbrido pues de uno y de otro-, Armenion encarna el ideal de un hombre armónico, que habiendo resuelto las disonancias de su carácter — nada se dice de un pasado turbulento, pero se deja intuir- está en condiciones de enfrentar el futuro, junto a Emilia, desde un nivel más elevado de conciencia y efectividad políticas que el impetuoso Eduardo, convirtiendo su amor en el ejemplo vivo de una relación tan bella que sea capaz de desplegar su luminoso influjo, en una patria en paz, entre quienes la circundan. Así, al menos, parece entenderlo el padre cuando exclama:

\section{«[...] Con agrado}

«prodiga sus alegrías un corazón libre;

«como el sol, que desde su áurea plenitud «entrega sus rayos al día con amor, esparce «su resplandor entre los buenos y los envuelve «en un círculo de luz y de placer toda su vida.

«Florece, primavera de mis hijos; no envejezcas «demasiado pronto y madura con belleza! ${ }^{19}$

Hölderlin se mantiene fiel en este punto al rasgo fundamental con que Schiller había caracterizado el idilio del género sentimental: «La impresión dominante de esta forma poética sería la serenidad, pero la serenidad de la perfección, no la de la indolencia; serenidad que fluye del equilibrio, no del estancamiento de las fuerzas; de la plenitud, no de la vaciedad, y que se acompaña de un sentimiento de infinito poder» (Schiller, 126-127).

El 10 de enero de 1797, desde Fráncfort, Hölderlin había escrito a Johann Gottfried Ebel, a la sazón en París: «Creo en una futura revolución de las ideas y modos de representación que hará enrojecer de vergüenza a todo lo anterior. Y Alemania tal vez pueda contribuir mucho a ello». ${ }^{20}$

El poeta Hiperión, en sus cartas, crea una imagen del desarrollo histórico e individual y ejerce a su través

${ }_{19}$ Hölderlin, F. (1999): Emilia en vísperas de su boda. Trad. de Anacleto Ferrer. Hiperión, Madrid, vv. 565-572.

20 HCC, n ${ }^{\circ} 132$. como educador de su pueblo. Recordemos que ese era el destino que Diotima le había vaticinado poco antes de morir. El apacible Armenion, «como el sol», «esparce / su resplandor entre los buenos y los envuelve / en un círculo de luz y de placer». Si la novela Hiperión es la primera contribución de Hölderlin a la «futura revolución de las ideas y modos de representación» que tendrá su epicentro en Alemania, este idilio para lectoras constituye la segunda.

Heroísmo trágico y armonía idílica, dos maneras distintas de modular los tonos para escribir, en lo esencial, la misma historia.

\section{La tragedia}

Como sabemos Hölderlin escribió el Plan de Fráncfort, en el que esboza por primera vez los problemas de la tragedia Empédocles, en el mismo cuaderno al que había confiado algunos borradores del segundo volumen de Hiperión. No era fruto del azar. En efecto, el destino del pensador de Agrigento parece responder ejemplarmente a lo que constituye la inspiración fundamental de la novela: la nostalgia de la unidad perdida, el esfuerzo por restaurar el Uno y Todo, ese incontenible impulso hacia el magma primordial de la gran naturaleza que Beda Allemann ha caracterizado como «el espíritu del río» (15).

$\mathrm{Y}$ es precisamente al final de Hiperión o el eremita en Grecia, en la respuesta a la carta de Notara en que le informa de la muerte de Diotima, donde el protagonista recuerda cómo nada más arribar a Sicilia desde Paros subió al Etna: «Allí recordé al gran siciliano que antiguamente, harto de contar las horas, emparentado con el alma del mundo, y a pesar de su temerario gusto por la vida, se arrojó a las poderosas llamas» (Hiperión, 1992: 202) (Hölderlin, 202).

Esa misma fascinación por el agrigentino la expresa la oda Empédocles, compuesta probablemente en las postrimerías del verano de 1797 en el reverso de la hoja en que figura el proyecto de oda dedicada a Bonaparte (Hölderlin, 105): 
Buscas y buscas la vida y surge y reluce para ti un fuego divino desde las profundidades de la tierra, y en tu estremecedor anhelo te arrojas allá abajo, a las llamas del Etna. $[\ldots]$

Pero para mí eres sagrado, como el poder de la tierra que te arrebató, ¡oh intrépida víctima!

$\mathrm{Y}$, si no me retuviera el amor,

seguir quisiera al héroe a las profundidades. ${ }^{21}$

En ambos textos, la novela y el poema, se alude a Empédocles como al poeta cuyo heroico afán de infinitud le lleva a renunciar al fatigoso recorrido de la «órbita excéntrica». La idea de que la necesidad e inevitabilidad de la muerte es la condición de posibilidad de la reintegración en el Todo de la naturaleza le impide aceptar una «antropodicea del padecer», como asiente a ella el Hiperión que narra la historia de su vida pasada a Bellarmino (Gaier, 290).

El interés de Hölderlin por la legendaria figura del filósofo de Acragas hunde sus raíces en la lectura, entre otras obras de carácter filológico e histórico que conoce durante su estancia en el seminario de Tubinga, de las Vidas de filósofos ilustres de Diógenes Laercio. En una carta del 24 de diciembre de 1798 a Isaac von Sinclair el poeta dice acerca de la que es su principal fuente:

Estos días he estado leyendo a tu Diógenes Laercio. Allí he descubierto algo con lo que ya me he topado otras veces, a saber, que lo pasajero y cambiante de los pensamientos y sistemas humanos me ha parecido de modo casi más trágico que los destinos que normalmente se denominan los únicos verdaderos, y creo que es natural, pues si el hombre en su actividad más propia y libre, e incluso en los pensamientos independientes, depende de una influencia extraña, y si incluso en eso sigue estando modificado por las circunstancias y el clima, lo que prueba de modo indiscutible, ¿en dónde reside entonces su dominio? También es bueno, y hasta constituye la primera condición de toda vida y organización, que no haya ninguna fuerza monárquica en el cielo ni sobre la tierra. ${ }^{22}$

${ }^{21}$ Hölderlin, F., Odas, p. 105

22 HCC, $\mathrm{n}^{\circ} 171$.
El rechazo de las ideas monárquicas tanto en filosofía como en religión y política constituye el más genuino elemento de empatía entre Empédocles y Hölderlin, en un momento en que, como éste reconoce, «la monarquía absoluta se está aboliendo por sí misma en todas partes». También en Wurtemberg, su patria. Al menos en eso confía él, que aborda su Empédocles «teniendo como punto de mira la esperada República Suaba» (Bertaux, 114).

Cuando Hölderlin, en julio de 1799, remite a Neuffer la carta en la que le explica por qué la tragedia es «la más estricta de todas las formas poéticas», ${ }^{23}$ había abandonado ya la primera versión de Empédocles. La segunda y la tercera quedarán igualmente inconclusas.

\section{Las muertes de Empédocles}

Como el Ser en Aristóteles, lo absoluto se dice en Hölderlin de diversas maneras. En Empédocles es la muerte libremente asumida entendida como redención o como retorno a la naturaleza y unión con ella o con los dioses. Pero la concepción del personaje y de la propia tragedia experimenta modificaciones sustanciales en las distintas variaciones compuestas por el poeta y, más que de la muerte, cabe hablar aquí, con toda legitimidad, de las muertes de Empédocles.

Saber lo que justifica la decisión de Empédocles, en qué se funda su resolución de morir, a qué instancias apela para legitimar su sacrificio, es también saber quién es él (Courtine, 20). El núcleo de la acción de la tragedia es el siguiente: Empédocles, el predilecto de los dioses, pierde la unidad con ellos y con la naturaleza - la motivación de tal pérdida es diferente en cada una de las versiones-, después es expulsado de la comunidad de los hombres y, finalmente, se suicida.

Unidad, separación, naturaleza como absoluto y muerte sacrificial del protagonista son los ejes conceptuales en que pivotan los tres fragmentos de tragedia y el Fundamento para Empédocles. 
Las redacciones sucesivas del proyecto dramático ensayan ese «rechazo decidido de lo accidental» que Hölderlin exige a la tragedia. ${ }^{24} \mathrm{Y}$ en ese progresivo despojamiento de la realidad la acción tiende a elidir todo lo que puede crear un verdadero movimiento dramático: la política, las pasiones, los conflictos interpersonales... Acaso sea en esta pretensión contradictoria donde haya que buscar las causas del fracaso de la tentativa trágica.

\subsection{El Plan de Fráncfort}

La primera caracterización de Empédocles es puramente personal y psicológica. En el Plan de Fráncfort — surgido a finales del verano de 1797- lo que motiva el suicidio del Siciliano es la sensación de hastío existencial, el horror a la temporalidad y a la limitación, a la positividad en el sentido de Hegel, que en enero de ese mismo año se ha instalado en la ciudad del Meno por intermediación de Hölderlin: ${ }^{25}$

Empédocles, inducido por su sensibilidad y su filosofía hace ya algún tiempo a odiar la cultura, a despreciar toda ocupación muy definida, todo interés dirigido a objetos diferenciados, enemigo mortal de toda existencia unilateral y, por tanto, insatisfecho, inestable, doliente, incluso en condiciones realmente bellas, simplemente porque son condiciones particulares y solo le satisfacen plenamente porque él no puede, con corazón omnipresente amarlas y habitarlas, férvido como un dios, libre y extenso como un dios, simplemente porque, tan pronto como su corazón y su pensamiento abrazan lo existente, está ligado a la ley de la sucesión...(Hölderlin, 25).

Un hombre así no parece necesitar una causa exterior para acabar suicidándose, por más que, como puede leerse en el «Acto cuarto», «quienes le envidian» manipulen al pueblo amotinándolo en contra suya.

Desde la primera versión, redactada en el otoño de 1798 después de que el poeta hubiese abandonado la casa de los Gontard y se instalara en la cercana Hom-

25 Jamme, Ch. (1983): «Liebe, Schicksal und Tragik. Hegels 'Geist des Christentums' und Hölderlins 'Empedockles'», en Jamme, Ch. y Pöggeler, O. (ed.), ,Frankfurt aber ist der Nabel dieser Erde». Das Schicksal einer Generation der Goethezeit. Klett-Cotta, Stuttgart, pp. 300-324.
}

burgo, Hölderlin modifica considerablemente el esquema de Fráncfort y deja de lado todos los episodios domésticos destinados a retardar la decisión de la muerte voluntaria. En los fragmentos siguientes Empédocles ya no tiene mujer ni hijos. Para profundizar en las motivaciones esenciales del suicidio del héroe, necesita elaborar el problema trágico despojando la acción dramática de los «motivos contingentes», de todo «lo accidental».

\subsection{Variación de Tántalo}

Empédocles es ahora un hombre que «Libre de necesidades, se mueve / en su propio mundo; con la dulce calma de los dioses» ${ }^{26}$ y solo de vez en cuando sale «a mezclarse con el pueblo». ${ }^{27}$ «Quienes le envidian» tienen ya nombre: son Critias, el arconte, y Hermócrates, el sacerdote. Temen que use su poder para soliviantar al pueblo. Para evitar que el taumaturgo pueda alcanzar poder político, Hermócrates, el principal antagonista de Empédocles y encarnación de los valores conservadores que tradicionalmente han regido la sociedad (Prignitz, 45), lo acusa de haberse proclamado «un dios ante todo el pueblo» (Hölderlin, 181). Su delito es - como el del «antiguo Tántalo, que estuvo más cerca de los dioses de lo que podía soportar», según le explicará a Böhlendorff el 4 de diciembre de $1801^{28}$ — el orgullo desmedido, la desenfrenada arrogancia:

Fui amado, amado por vosotros, oh dioses...

¡Oh imagen espectral, no te lo ocultes! Tú mismo te has cargado de culpa, pobre Tántalo; has profanado el santuario; has truncado la bella alianza con insolente orgullo ¡miserable! ¡Cuando los genios del mundo, llenos de amor, en ti se olvidaban de sí mismos, pensaste solo en ti e imaginaste, pobre necio, que a ti los bondadosos se vendían, y que los celestiales, como esclavos tontos, te servían! ${ }^{29}$

\footnotetext{
Hölderlin, F., Empédocles, vv. 71-72.

Ibid., v. 85.

HCC, n ${ }^{\circ} 236$.

29 Hölderlin, F., Empédocles, vv. 312-321.
} 
Expiar el pecado por la bybris de la autodeificación - en el que es reconocible la misma crítica a la voluntad de poder del espíritu, característica del pensamiento de Fichte, con que arrancaban las versiones de Hiperión compuestas en Jena y Weimar: «la escuela del destino y los sabios me había hecho injusto y tiránico con la naturaleza» (Hölderlin, 71) — parece ser el móvil primero de su decisión de buscar el fatal desenlace de una muerte trágica:

\footnotetext{
¡No debería expresarlo, sacra naturaleza!

¡Vosotras, potencias puras, siempre jóvenes,

que me habéis criado con gozo

y nutrido con delicias! Los dioses se habían

puesto a mi servicio, yo solo

era dios y lo proclamé con atrevido orgullo.

¡Oh créeme, más me hubiese valido

no nacer! ${ }^{30}$
}

La exclamación final recuerda el moto de Sófocles (Edipo en Colono, vv. 1224-1227) que encabeza el segundo volumen de Hiperión: «No haber nacido aventaja / a cualquier otra consideración, y, de haber nacido, / volver cuanto antes allá, precisamente de donde se ha venido, / es con mucho lo segundo mejon» (Sófocles, 387), que en la novela era contradicho mediante el pensamiento de la «órbita excéntrica». La forma artística de la tragedia también guarda una estrecha afinidad con el segundo Edipo de Sófocles, cuyo tema son los días postreros del héroe tebano, quien, después de haber sufrido las mayores desgracias, vagabundea por Grecia acompañado de su hija Antígona, cuando ya solo le queda el consuelo de encontrar un lugar donde su cuerpo descanse.

Las vacilaciones del pueblo entre Empédocles y el sacerdote Hermócrates se van convirtiendo en el transcurso del drama en la razón fundamental del suicido. Cuando en la «Escena cuarta» del «Acto segundo» los agrigentinos vuelvan a acudir al filósofo y le ofrezcan la corona, les responderá que «Ya no es éste tiempo de reyes». ${ }^{31} \mathrm{El}$ presente no puede conformarse con el

\footnotetext{
Hölderlin, F., Empédocles, vv. 448-454.

31 Hölderlin, F., Empédocles, v. 1325.
}

modelo de dominación antiguo - recordemos lo que Hölderlin había escrito a Sinclair a propósito de la «monarquía» y los tiempos que se avecinaban-, sino aspirar a uno nuevo basado en las iniciativas de un pueblo maduro capaz de propiciar un rejuvenecimiento de las estructuras y valores sociales que brote de la máxima intimidad con la naturaleza, la instancia legitimadora por antonomasia que Hölderlin comparte con los pensadores revolucionarios del siglo XVIII, con Rousseau a la cabeza:

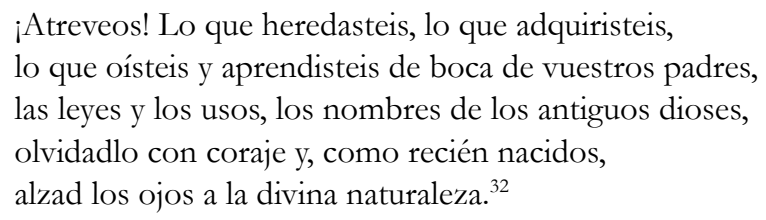

¡Atreveos! Lo que heredasteis, lo que adquiristeis, lo que oísteis y aprendisteis de boca de vuestros padres, las leyes y los usos, los nombres de los antiguos dioses, olvidadlo con coraje y, como recién nacidos, alzad los ojos a la divina naturaleza. ${ }^{32}$

El protagonista de la tragedia obtiene su poder de la comunión con la naturaleza, y por eso el mensaje que difunde entre sus conciudadanos apunta a un renovado orden social inspirado en ella. Oficia de mediador entre la armónica esfera natural y la disarmónica esfera humana. Su existencia oscila entre los dos ámbitos: él es la epifanía de los dioses. En la medida en que muestra el camino a seguir a los agrigentinos, su tarea está cumplida y su muerte deviene ineluctable, necesaria, pues impide la idolatría y la tiranía, al tiempo que deja tras de sí un referente simbólico de plenitud que impelerá a los hombres a materializar en la historia sus relumbres.

Empédocles es el centro indiscutible de esta primera variación, esencialmente monológica. En ella todo gira alrededor de los pensamientos del protagonista, en cambio el pueblo de Agrigento solo aparece como un pelele, incapaz de actuar motu proprio, en manos del poder político y del religioso. Probablemente es esa debilidad dramática — unida a los titubeos acerca de la motivación esencial que fundamenta la necesidad de la muerte del héroe trágico: si subjetiva (el pecado de bybris), si objetiva (impedir el retorno al antiguo orden)la que lleva a Hölderlin a abandonar esta versión y a iniciar la siguiente.

\footnotetext{
32 Ibid., vv. 1411-1415.
} 


\subsection{Variación de Prometeo}

La segunda versión mantiene la contraposición entre Hermócrates y Empédocles. De nuevo el sacerdote quiere acabar con el filósofo, al que ahora más sutilmente acusa de profanar lo divino al revelar a las masas su secreto. No obstante, y a diferencia de lo que ocurría en la variación anterior, el pragmático Hermócrates de esta segunda tentativa se siente más próximo al héroe de la tragedia, tal y como le confiesa a Mecades, el joven repúblico que sustituye ahora al arconte:

\section{[...] Este hombre debe caer; \\ te lo digo y créeme, si fuese posible respetarlo, \\ lo haría más que tú. Pues está más cerca \\ de mí que de ti. Pero debes aprender esto: \\ más pernicioso que la espada y el fuego \\ es el espíritu del hombre, semejante al de los dioses, cuando no sabe callar ni mantener \\ sin desvelar su secreto $\left[\ldots . . .^{33}\right.$}

La decisión de Hölderlin de atemperar el aislamiento de Empédocles se hace visible en la matizada descripción de su falta, que ya no es la de haberse proclamado un dios ante el pueblo ignorante, sino la de robar al cielo «la llama de la vida» ${ }^{34}$ y revelársela a los hombres. Como el del titán responsable de asaltar los cielos, una de las divinidades predilectas del Romanticismo - que, al robar el fuego sagrado para entregarlo a los mortales incurre en el castigo divino-, el delito de Empédocles solo puede ahora entenderse desde su prometeísmo: traicionar a su propia clase en beneficio del pueblo (Constantine, 81). Según informa Mecades, Empédocles se ha dirigido al pueblo en el Ágora con estas palabras:

Porque yo aúno lo ajeno, mi palabra da nombre a lo ignoto, y el amor de los vivos, soy yo quien lo lleva de acá para allá; lo que le falta a uno, lo quito de otro,

33 Ibid., vv. 163-170.

34 Ibid., v. 36. y enlazo animando, y ambulo rejuveneciendo el mundo vacilante, y me asemejo a ninguno y a todos. ${ }^{35}$

El pecado de Empédocles ya no es la bybris de la autodeificación. Su falta es haber pretendido unir con su palabra las esferas de lo finito y lo infinito, de lo divino y lo humano. Los argumentos de Hermócrates ya no son mera expresión de sus ansias personales de poder, sino de la objetiva oposición al entusiasmo por el que el pueblo se ha dejado arrebatar tras la irrupción de Empédocles en la escena social. Sabe que el contacto con lo absoluto resulta destructivo, y por eso mantiene a los hombres conscientemente separados de la divinidad, en estado de ceguera:

Por esta razón también, ponemos

a los hombres una venda en los ojos,

para que no se nutran de demasiada luz. ${ }^{36}$

También las dudas de Delia, al defender el punto de vista de la vida frente al de un suicidio que se le antoja sin sentido, en contraposición a la incondicional admiración de Pantea por todo cuanto haga y diga el filósofo-dios, el médico-taumaturgo que — según sabemos por Laercio (136) — la salvó de la muerte, reciben en esta versión un peso mayor. Pero con tales dudas comienzan asimismo las dificultades de Hölderlin para poder justificar dramáticamente el suicidio de Empédocles: «porque ¿cómo puede alguien que anuncia una nueva vida buscar al mismo tiempo la muerte?» (Knaupp, 19). ¿Qué le autoriza a Empédocles a inmolarse como víctima sagrada? ¿No será su muerte autoelegida otro gesto de arrogancia? Delia tiene razón, cuando concluye:

Con demasiada complacencia, Empédocles, con demasiada complacencia te inmolas. ${ }^{37}$

\footnotetext{
Hölderlin, F., Empédocles, vv. 126-133.

Ibid., vv. 10-12.

37 Hölderlin, F., Empédocles, vv. 656-657.
} 


\subsection{Interludio poetológico}

Si bien el poeta huye de la obsesión germánica por las construcciones sistemáticas y racionales como medio para resolver los enigmas del mundo y de los hombres, no es menos cierto que su actitud indagatoria le impele a consideraciones de carácter filosófico cada vez que tiene un asunto importante que dilucidar. Eso son sus ensayos: testimonios de las cavilaciones que acompañan y aguijonean su quehacer poético.

Hölderlin debió de darse cuenta de que tenía que reformular la cuestión del suicidio del protagonista si quería acabar la tragedia. Alrededor de este problema gira el escrito poetológico La oda trágica..., y el Fundamento para Empédocles contenido en él, que seguramente escribió en septiembre de 1799 como necesaria autoclarificación antes de emprender la tercera versión. Los esfuerzos por llevar a término su plan provocan una reflexión teórica en la que concluye la dilucidación acerca de la relación dialéctica entre naturaleza infinita - lo originariamente uno, lo aórgico- y arte, cultura o conciencia - lo opuesto en sí, el principio burgués de la división del trabajo (Safranski, 184). lo orgánico_ con la siguiente frase:

Este sentimiento quizá se halle entre lo más elevado que el ser humano pueda experimentar, porque la armonía actual le hace recordar la relación, inversa y pura, y se siente a sí mismo y a la naturaleza doblemente, y su unión es más infinita (Ibid., 287-289).

Este sentimiento es el del poeta que Hölderlin ejemplifica con la muerte de Empédocles (Gutiérrez, 18). El hombre en el que se concilian los extremos de su tiempo «demasiado íntimamente», sin ser completamente capaz de difundir el sentimiento y el conocimiento de la unificación con todo lo viviente también entre los otros, debe sucumbir, porque no es posible una solución individual para el destino de toda una época. Por mor de la revolución social, por amor a los demás, Empédocles tiene que inmolarse. Hölderlin afirma que Empédocles había «nacido para poeta», pero llega a la conclusión de que la época en que éste vivió no tenía necesidad de la palabra, «tampoco exigía auténtica acción», tan solo reclamaba una víctima:

Exigía un sacrificio, en el que el ser humano completo se hace real y visiblemente aquello en lo que el destino de su tiempo parece resolverse, en lo que los extremos parecen conciliarse real y visiblemente en una unidad, pero, precisamente por eso, están demasiado íntimamente unificados, y por eso el individuo sucumbe y tiene que sucumbir en una acción ideal, porque en él se mostró prematuramente la unificación sensible (Hölderlin, 295).

Ese fundamento especulativo de la muerte sacrificial explica también otro trágico deceso de un ser individual en la obra de Hölderlin: el de Diotima, encarnación del amor y la belleza, que son dos de las maneras en que se dice lo absoluto en Hiperión.

\subsection{Variación de Cristo}

Si las dos primeras versiones se habían alejado del Plan de Fráncfort resolviendo la inevitabilidad de la muerte de Empédocles no en una necesidad intrínseca a su ser, como se lee en el proyecto originario, sino en una opuesta búsqueda de motivaciones que encontraba una salida dramatúrgicamente válida en la introducción del concepto de culpa, la tercera - emprendida a finales de 1799- pretende recuperar, debidamente fundamentada, la concepción en que se sustentaba implícitamente el esbozo primero: el deseo de muerte subjetivo irrumpe de nuevo con la radicalidad de aquel Plan.

El protagonista se desenvuelve otra vez en un tejido de relaciones familiares. No se trata de una mujer y unos hijos, como en el Plan de Fráncfort, sino de un hermano (Estratón, señor de Agrigento) y una hermana (Pantea). Mientras el primero ejerce como verdadera contrafigura del héroe, la segunda desempeña funciones de mediación entre las posiciones encontradas de ambos. La tragedia apenas está esbozada.

Siguiendo el modelo de Eurípides, que abre sus dramas con una gran plática prologal, la tercera variación comienza con un largo monólogo del protagonista. La 
introducción de un coro muestra también su aproximación a las tragedias antiguas. La acción tiende a abandonar la escena política y Empédocles se va viendo constreñido al rol de un Cristo pagano. Así, cuando el anciano egipcio Manes — «el omniexperimentado, el visionario» (Hölderlim 369)- - señala la necesidad de un único y nuevo salvador, que reconcilie, con su propia inmolación, a los humanos con los dioses y a la naturaleza con el arte, le pregunta: «¿Eres tú ese hombre?, ¿el mismo?, ¿lo eres?». ${ }^{38}$ De la autocomprensión de Empédocles se deriva la necesidad de su muerte, para que la unificación no permanezca ligada a su sola persona, sino que pueda generalizarse, tal y como explicaba el Fundamento.

En esta versión la figura de Empédocles, despojada finalmente de entidad dramática en consonancia con el precepto poetológico que exigía de la tragedia el «orgulloso rechazo de todo lo accidental», queda reducida al papel de medium al servicio de una legalidad histórica de rango superior. Pero en la acción teatral, la fabula se construye desde el devenir del diálogo entre personajes. No por mor de un imperativo teórico extradiegético. Así que para acabar presentando la inevitabilidad de la muerte del héroe trágico como solución a un teorema filosófico-histórico, hubiese sido mucho más pertinente un ensayo que un drama. Llegados a este punto, Hölderlin no sabe cómo continuar. No puede: en su pecado llevaba implícita ya la penitencia.

También los cambios que se suceden en la situación política sudalemana a lo largo de 1799 influyen en la paralización de un proyecto literario con el que Hölderlin pretendía arrojar luz sobre la necesidad y las condiciones de una transformación cultural profunda, creando a partir de una materia antigua un modelo analógico del presente que reflejase sus propias esperanzas revolucionarias. A principios de 1799 el Directorio, que había utilizado la amenaza de revolución como un medio para apartar a los pequeños y medianos príncipes de la influencia austríaca y vincularlos con Francia, envía a Stuttgart a su delegado oficial con la misión de distanciarse de los patriotas wurtemburgueses. El gobierno francés prefería antes un príncipe amistoso que una república convulsa. A finales de febrero estalla la Segunda Guerra de Coalición. Los revolucionarios suabos abrigan aún la esperanza de que con la reanudación de la contienda puedan verse realizados sus planes, pero el general Jourdan hace saber, por orden del Directorio, que los eventuales movimientos revolucionarios de los republicanos sudalemanes serían aplastados por las tropas francesas. Los revolucionarios suabos se quedan solos. La materia del drama había perdido su fundamento nutricio inmediato.

\section{Versiones y variaciones}

Sabemos que la música acompañó a Hölderlin a lo largo de toda su vida. De sus vidas. De la cordura y la locura. La variación, como forma musical, consiste en un número indeterminado de piezas breves basadas en un mismo tema, «el cual es modificado cada vez intrínseca o extrínsecamente» (Zamacois, 136). Algunas de las más conocidas son las Variaciones Goldberg, de Bach, y las 33 Variaciones para piano en Do mayor sobre un vals de Diabelli, de Beethoven, coetáneo del poeta. ¿Y qué otra cosa son, sino variaciones, en el sentido musical propuesto, las tres versiones fragmentarias del drama?

El tema: la libre asunción de una muerte conducente a una nueva afirmación de la vida. En Empédocles Hölderlin da hechura a su idea del poeta trágico, que para poder influir en su tiempo menesteroso ha de sacrificar su propia dicha. Su figura y su experiencia deberán proyectarse sobre la producción hímnica tardía, donde poetiza acerca de los peligros que acechan al vate en el ejercicio de su sagrada función.

Las variaciones, modificaciones intrínsecas o extrínsecas del tema, que constituye el elemento básico de la composición, dependen de la dialéctica entre los «tonos grandes, orgullosos y firmes» y el «rechazo decidido de lo accidental». 


\section{Coda: Dar nombre a 10 ignoto}

Bebo vino de dos vasos

Paul Celan

Como recurso no solo ni principalmente formal, la música estructuró algunos de los poemas más herméticos del que Nelly Sachs llamó «bendecido por Bach y Hölderlin» $\mathrm{y}$ «Hölderlin de nuestro tiempo» (Celan y Sachs).

La fuga, que es un estilo compositivo basado en la polifonía vertebrada por el contrapunto entre varias voces o líneas instrumentales, es el modo musical elegido por Paul Celan en Todesfuge (probablemente de 1945) para contrapuntar las voces de víctimas y victimarios en el campo de Auschwitz, desde la residencia de cuyo comandante se podían escuchar las fugas de Bach, incuestionable «Maestro de Alemania» (Meister aus Deutschland) en este arte. También Strette (Engfübrung, 1958), de nuevo sobre la experiencia concentracionaria, está compuesto a partir de la forma musical del «estrecho»o stretto, que es un recurso que se emplea en la fuga consistente en interrumpir la línea de una voz y reanudarla con otra voz distinta, tal y como ha demostrado Peter Szondi (59) en su ejemplar análisis del poema.

Las grandes elegías y los cánticos de Hölderlin, nacidos, a partir del ocaso de Empédocles, de la impotencia del poeta para articular dramáticamente la dicción de lo ignoto, exploran territorios que van de la lírica de la vivencia a la «desprendida alabanza de los dioses» (Szondi, 75) en los himnos tardíos, oscuros y paratácticos.

En el Discurso con motivo de la concesión del Premio de Literatura de la Ciudad Libre Hanseática de Bremen (1958), escribe Celan (498):

Puesto que es una manifestación del lenguaje y por tanto esencialmente dialógico, el poema puede ser una botella de mensaje lanzada con la confianza - no siempre muy esperanzadorade que pueda ser arrojada a tierra en algún lugar y en algún momento, tal vez a la tierra del corazón. De igual forma, los poemas están de camino: rumbo hacia algo.
¿Hacia qué? Hacia algo abierto, ocupable, tal vez hacia un tú asequible, hacia una realidad asequible a la palabra.

Tales realidades son las que tienen relevancia para el poema. ${ }^{39}$

Se encuentre donde se encuentre, lo ignoto, lo desconocido (Unbekannte), lo es porque aún no ha sido desvelado, porque aún no ha sido nombrado, su mensaje continúa encapsulado en el interior de una botella. Por eso mismo, «el poema quiere ser entendido: como poema, como 'oscuridad del poema'» (Celan, 101), «por un tú asequible», por un lector paciente y resiliente más interesado en los caminos que en los destinos finales.

\section{Referencias bibliográficas}

\section{Hölderlin}

Hölderlin, F. Hiperión o el eremita en Grecia. Madrid: Hiperión, 1976.

Hölderlin, F. Ensayos. Madrid: Hiperión, 1976.

Hölderlin, F. Hiperión. Versiones previas (HVP). Madrid: Hiperión, 1989.

Hölderlin, F. Correspondencia completa (HCC). Madrid: Hiperión, 1990.

Hölderlin, F. Sämtliche Werke und Briefe (SWB). Múnich: Carl Hanser Verlag, 1992 ss.

Hölderlin, F. Empédocles. Madrid: Hiperión, 1997.

Hölderlin, F. Odas. Madrid: Hiperión, 1999.

Hölderlin, F. Emilia en vísperas de su boda. Madrid: Hiperión, 1999.

\section{Celan}

Celan, P. Obras completas. Madrid: Trotta, 1999.

Celan, P. y Sachs, N. Correspondencia. Madrid: Trotta, 2007.

39 Celan, P. (1999): Obras completas. Trotta, Madrid, p. 498. 
Celan, P. Microlitos. Aforismos y textos en prosa. Madrid: Trotta, 2015.

\section{Secundarias}

Alleman, B. Hölderlin y Heidegger. Buenos Aires: Los libros del mirasol, 1965.

Arrighi, P. y Pomponi. F. Histoire de la Corse. París: Presses Universitaires de France, 1993.

Bertaux, P. Hölderlin y la Revolución Francesa. Barcelona: Ediciones del Serbal, 1992.

Constantine, D. Friedrich Hölderlin. Múnich: Verlag C.H. Beck,1992.

Courtine, J-F. «Qui est l'Empédocle de Hölderlin?». Nietzsche, Hölderlin et La Grèce. É. Gaède (ed.). Niza: Publicacions de la Faculté des Lettres et Sciences Humaines de Nice, 1985, No 34 (1re Série).

Gaier, U. Hölderlin. Eine Einfübrung. Tubinga: Francke Verlag, 1993.

Grätz, K. «Der Übergang vom Alten zum Neuen. Hölderlins Geschichtsauffassung in seiner Tragödie 'Der Tod des Empedokles'». Text+Kritik, VII, 1996, 99-117.

Gutiérrez Girardot, R. «Prólogo», Fiesta de la paæ. Friedrich Hölderlin. Bogotá: Áncora Editores, 1994.

Hock, E. «Zu Hölderlins Reise nach Kassel und Driburg». Hölderlin-Jabrbuch, 16, 1969-70, 254-290.
Jamme, Ch. (1983): «Liebe, Schicksal und Tragik. Hegels 'Geist des Christentums' und Hölderlins 'Empedockles'». «Frankfurt aber ist der Nabel dieser Erde». Das Schicksal einer Generation der Goethezeit. Ch. Jamme y O. Pöggeler. Stuttgart: Klett-Cotta, 1983.

Knaupp, M. «Prólogo». Empédocles. Friedrich Hölderlin. Madrid: Hiperión, 1997.

Laercio, D. Vidas de filósofos ilustres. Barcelona: Iberia, II, 1986.

Ludwig, E. Napoleón. Barcelona: Editorial Juventud, 1956.

Prignitz, Ch. Hölderlins «Empedokles». Die Vision einer erneuerten Gesellschaft und ibre zeitgeschichtlichen Hintergründe. Hamburgo: Helmut Buske Verlag, 1985.

Ryan, L. «Hier oben ist ein neues Vaterland'. Hölderlins Trauerspiel 'Der Tod des Empedokle». Bad Homburger Hölderlin-Vorträge, 1985, 33-48.

Safranski, R. Hölderlin o El fuego divino de la poesía. Barcelona: Tusquets, 2021.

Szondi, P. «Lectura de 'Strette'». Estudios sobre Celan. Madrid: Trotta, 2005.

Schiller, F. Sobre la gracia y la dignidad. Sobre poesía ingenua y poesía sentimental. Barcelona: Icaria, 1985.

Sófocles. Tragedias completas. Madrid: Cátedra, 1990.

Szondi, P. Estudios sobre Hölderlin. Barcelona: Destino, 1992.

Zamacois, J. Curso de formas musicales. EE.UU: SpanPress Universitaria, 1997. 